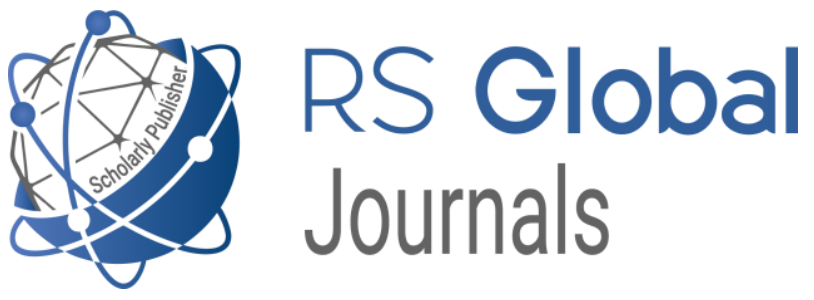

Scholarly Publisher

RS Global Sp. z O.O.

ISNI: 0000000484952390

Dolna 17, Warsaw, Poland 00-773

Tel: +48226022703

Email: editorial_office@rsglobal.pl

JOURNAL International Journal of Innovative Technologies in Social Science

p-ISSN

$2544-9338$

e-ISSN

2544-9435

PUBLISHER

RS Global Sp. z O.O., Poland

ARTICLE TITLE

INNOVATIVE BLENDED LEARNING METHODOLOGY IN TEACHING IT STUDENTS ENGLISH FOR PROFESSIONAL PURPOSES

AUTHOR(S) Lazorenko L. V.

Lazorenko L. V. (2021) Innovative Blended Learning

Methodology in Teaching it Students English for Professional

ARTICLE INFO Purposes. International Journal of Innovative Technologies in

Social Science. 3(31). doi:

10.31435/rsglobal_ijitss/30092021/7651

DOI

https://doi.org/10.31435/rsglobal_ijitss/30092021/7651

RECEIVED 14 June 2021

ACCEPTED 12 August 2021

PUBLISHED 17 August 2021

LICENSE

This work is licensed under a Creative Commons Attribution

4.0 International License.

(C) The author(s) 2021. This publication is an open access article. 


\title{
INNOVATIVE BLENDED LEARNING METHODOLOGY IN TEACHING IT STUDENTS ENGLISH FOR PROFESSIONAL PURPOSES
}

\author{
Lazorenko L. V., PhD, ass. prof., Taras Shevchenko National University of Kyiv, Ukraine, \\ ORCID ID: https://orcid.org/0000-0002-0067-7471
}

DOI: https://doi.org/10.31435/rsglobal_ijitss/30092021/7651

\section{ARTICLE INFO}

Received 14 June 2021

Accepted 12 August 2021

Published 17 August 2021

\section{KEYWORDS}

Blended Learning, Information Technologies, English to IT students, professionally oriented foreign language, traditional, distance and blended learning, competency-based learning model, innovative methods, higher education

\begin{abstract}
The purpose of this article is to analyze the history of the methodology and the concept of Blended Learning, give examples, systematize, classify and identify the most effective models of blended learning in teaching English to IT students based on the study of their research and use in higher education all over the world. The article proves the necessity of finding innovative technologies for the effective teaching of a professionally oriented foreign language in the field of Information Technologies. Methodical literature, speeches, reports and reports at modern educational conferences, forums are analyzed. The article shows the advantages and disadvantages of using these models, offers examples of research technology Blended Learning. The difference between traditional, distance and blended learning is characterized and shown. Examples are given and models of blended learning are shown schematically. The specifics of the organization of work with one of the resources in the context of blended learning are considered.
\end{abstract}

Citation: Lazorenko L. V. (2021) Innovative Blended Learning Methodology in Teaching it Students English for Professional Purposes. International Journal of Innovative Technologies in Social Science. 3(31). doi: 10.31435/rsglobal_ijitss/30092021/7651

Copyright: (C) 2021 Lazorenko L. V. This is an open-access article distributed under the terms of the Creative Commons Attribution License (CC BY). The use, distribution or reproduction in other forums is permitted, provided the original author(s) or licensor are credited and that the original publication in this journal is cited, in accordance with accepted academic practice. No use, distribution or reproduction is permitted which does not comply with these terms.

Methods used to solve the tasks: methods of theoretical analysis, the study of scientific and methodological literature, Internet resources on research issues and a description of the experience of using the model in the educational process of IT faculties.

Introduction. The implementation of a competency-based learning model, which aims to reform the higher education system, requires the application of the latest learning information technologies. Supervisors of higher education institutions have a task to help IT students take an active part in international conferences, seminars, projects, internships, that is to provide students with the necessary knowledge and skills to meet IT students' requirements of the modern labour market. To accomplish this task, university professors must be constantly looking for innovative methods and technologies for teaching a foreign language for professional purposes.

Unfortunately, the amount of hours, devoted to learning a foreign language in the classroom format, does not allow to contain all the information that a student needs to achieve the appropriate level of proficiency in a professionally oriented foreign language. Adds certain difficulties to students in groups with different levels of training, different levels of foreign language proficiency. These and other problems need to be solved through the modern organization of the educational process.

One of the specific possible ways to optimize the educational process, we propose to consider "blended learning". We consider the value of "blended learning" to be especially accurate for the training of IT students, who need to master the skills of independent search, selection, processing of necessary information, the ability to quickly find ways to solve a problem situation, constantly improve their professional skills. 
According to the participants of the international project EDUCAUSE, the technology of blended learning is a "driver" of innovative development of higher education in the world. (EDUCAUSE. 2018)

The international report "NMC Horizon: Higher Education-2017" notes the effectiveness of blended learning in universities, the importance of its role in shaping the adaptive individualized way of acquiring knowledge and skills for each student. This is due to the focus on a student-centred approach, shifting the emphasis on students' independent work. In addition, blended learning is one of the mechanisms for organizing a flexible learning process in the transformation of the educational system. (Adams Becker S. et al., 2017)

\section{Analysis, history.}

Blended learning is an educational approach that combines teacher-based learning (traditional) and online education.

The concept of "blended learning" originated in the 1920s when American schools began to use the correspondence between teachers and students, the term itself was first used in 1999 when the American Interactive Learning Center started producing software designed for teaching online. Nowadays, electronic interaction of participants in the educational process has become the norm and is increasingly used in education: communication with students via e-mail, chats in messengers (Telegram, Viber, WatsUp), use of Google Classroom, e-learning resources, electronic educational platforms, online -testing and others.

After analyzing the scientific literature, we can conclude that there are several terms to define the concept of "blended learning". For example, the term "hybrid" (hybrid), "blended learning" (mixed-mode), "integrated learning" (web-enhanced) and others are widely used.

In defining blended learning, scientists also did not come to a single definition. Thus, E. Banados believes that blended learning is a combination of traditional classroom learning and computer technology based on a flexible approach to learning that takes into account the benefits of training and test tasks in electronic form, and uses methods to improve student outcomes and reduce tuition costs (Banados E., 2006).

C. J Bonk. \& C. R. Graham consider blended learning a combination of personal learning (FACE-TO-FACE) and computer-based learning (CAL). (Bonk C. J. \& Graham C. R., 2005)

G. Dudeney, N. Hockly, and E. Stracke explain blended learning as a language course that combines learning through personal communication with appropriate use of technology. (Dudeney G., Hockly N., 2010, P. 57-78.)

The Clayton Christensen Institute provides a more specific definition: "Blended learning is an educational approach that combines face-to-face learning with online learning and provides elements of student self-monitoring of the way, time, place and pace of learning, as well as the integration of teaching experience with the teacher and online. (www.christenseninstitute.org). R. Harrison and $H$. Kanuka generally point out that blended learning is a departure from either approach. They emphasize that this is a fundamental rethinking and reorganization of the dynamics of teaching and learning, starting with different contextual needs and unforeseen circumstances (such as level of development, training, resources, discipline). (Garrison, R., \& Kanuka, H., 2004)

Another view, for example, is that David W. Johnson considers blended learning to be a combination of formal and non-formal learning tools (classroom lessons, learning the theoretical component with discussion via e-mail, chat or webinar. (David W. Johnson et al., 1994)

It is important to recognise the difference between "Blended Learning" and "Distance" (Distance Learning) and "Mixed" and "Traditional" (Face-to-Face Learning or Brick-and-Mortar) learning. In the first case, the student has no face-to-face contact with the tutor, in the second case, the student acquires knowledge only during classroom classes and receives information from the professor, from textbooks, etc.

Going deeper into the definition of "blended learning", we can mention the opinion of Steve Wheeler that it is based on a combination of two types: online and traditional. We agree that some of the examples he lists are a combination of online and personal learning, between synchronous and asynchronous activities, between mobile and traditional learning experiences. Steve Wheeler emphasizes that blended learning is becoming an increasingly complex concept with many possibilities and endless options. Blended Learning is the choice and maximization of learning in more convenient modes. "Training in all its forms is a bit like a blender in your kitchen. Add the necessary ingredients and make a little effort, and we hope the result will be very useful. (http://www.steve-wheeler.co.uk/) 


\section{Types of traditional, distance and blended learning.}

To determine the most effective type of training, we propose to consider the main types with a brief description:

D-learning (distance learning) is a method that allows you to learn remotely. The student does not meet with the professor and other students in real time. In this case, two-way communication is an obligation. Ways of cooperation: email, Skype, Zoom, Google resources, etc.

E-learning is one of the types of distance learning, where a student needs to have a computer (tablet, smartphone) with Internet access. Thanks to e-learning you can participate in seminars, discussions, etc. E-learning is suitable for classes in small groups and for teaching a large number of people at the same time.

M-learning (mobile learning) - one of the subtypes of E-learning, which uses an electronic device with a stable Internet connection.

B-learning (blended learning) - blended learning. A method that successfully combines traditional and distance learning. Different forms of communication are used depending on the objectives of the course: if you need to improve practical skills, students are engaged in a stationary classroom, at the same time part of the information is sent by the teacher by email, chat, taught in the form of video lectures. From time to time students meet with the teacher online at webinars, video conferences, etc.

Examples:

Webinar - is presentation, lecture, seminar, practice, which is organized using webcast technology. During the webinar, two-way communication between the professor and students is provided, while synchronous learning is a very successful application: discussions, brainstorming, etc. The webinar requires an online room, a website, where the webinar or conference takes place. The coach has the opportunity to demonstrate additional materials, leave notes on the interactive whiteboard, use additional tools. Students have the opportunity to communicate with each other and with the teacher, ask questions in the chat with text messages or with a microphone.

The Autowebinar is a recorded webinar or lecture that can be viewed if it was not possible to attend the webinar directly during the webinar. The disadvantage of autowebinar is that it is only an imitation of live communication, there is no possibility to ask questions during the lecture, to get feedback in time.

Chat-session is conducted synchronously, ie at the same time all participants must connect to a certain office.

Web classes - classes, laboratory practice, conferences, seminars, business games, workshops via the Internet. Both synchronous and asynchronous interaction is possible.

Teleconference - tasks are sent to students by e-mail, i.e. the student has to do homework, combining theoretical knowledge with practical exercises.

Videoconference - a synchronous program for simultaneous communication between students and teachers (seminar, conference, etc.)

Asynchronous programs - the student has the opportunity at a convenient time to practice the material. Interaction is carried out with the help of Internet resources and sending materials personally to the teacher by e-mail.

Traditional education involves daily visits to the physical space at a fixed time for receiving personal instruction. Traditional learning can take the form of lectures, group or individual projects, lab work, demonstrations, Powerpoint presentations, etc., but does not include online learning modules. In addition, teachers also often give students supplementary materials (usually printed) that need to be done without further instructions, such as homework. Students complete assignments several weeks or months before the end of the course.

According to Dewey (1938), in traditional groups, educators are responsible for systematically communicating information, skills, standards, and rules of conduct to students and adhering to the system. (http://www.e-learn.nl/2015/07/20/defining-blended-learning)

Distance Learning.

For productive learning, power of professional skills, the teacher must provide profitable feedback to students. Thus, a systematic check of understanding and perception of the material becomes one of the necessary tasks of the teacher.

Distance learning is primarily the interaction of students and teachers at a distance, while it contains almost all the components that we use during the learning process: methods, goals, content, 
organizational forms, and sometimes learning tools. Distance learning is realized employing telecommunication (digital) technologies, which provide interactivity of the learning process. During distance learning, it does not matter where the participants are, only the availability of a computer and access to the Internet is important. This became possible due to the development of information technology. To be successful today, it is necessary to constantly develop, learn, acquire new knowledge, skills and abilities, improving professional skills, and it is not possible to have time in real-time.

From this point of view, distance learning has significant advantages:

$\checkmark$ Convenient and flexible form of learning (including the material is independent, regardless of the schedule, this is especially true for working students)

$\checkmark$ Save time on the trip to the place of study (transport, premises)

$\checkmark$ Specific knowledge (no "extra" surpluses of academic education)

$\checkmark$ Relevance of knowledge (instant access to the latest research, electronic resources (libraries, databases...))

$\checkmark$ Ability to simultaneously study a large number of students

$\checkmark$ Improving the quality of education through the use of information tools and technologies (conducting online tests)

$\checkmark$ The distance learning program aims to fully immerse students in the educational process and further self-education.

$\checkmark$ During distance learning, the teacher should provide online support, information assistance, and from time to time provide advice on questions on the topic.

$\checkmark$ The teacher has the opportunity to choose the best resources from the Internet

$\checkmark$ Students who are ashamed sometimes become more active

At the same time, distance learning has certain disadvantages:

- Lack of practical classes ("live" communication with teachers and students)

- Inability to involve all participants in the general discussion (usually 1-3 students are not included in the discussion)

- Lack of practice in most educators in conducting online training

- Methods used in teaching certain subjects (physics, mathematics), where it is necessary to perform special stages (practical work) sometimes become ineffective

- There is no guarantee of self-fulfilment of the task

- The need for a separate site (online office) to manage the distance learning process.

- Lack of personal communication (to produce new ideas)

- Lack of certain skills for development (for example, the process of taking notes teaches the student to extract important information, develops memory, trains mechanical sensory skills, fine motor skills)

- Dependence on technical means of training (video conference failure due to lack of Internet, uncharged gadget)

- Lack of constant control (requires strong motivation from the student, self-discipline)

It is possible that if Bill Gates had studied at Harvard remotely, he would not have met Steven Anthony Ballmer and founded Microsoft.

\section{Presenting main material.}

The basis of technological models of blended learning is the technological dominance of the design of the educational process. Higher education research conducted at the Clayton Christensen Institute (an organization that implements and applies the ideas of "explosive innovation" in medicine, education, research, etc.) aims to find innovative solutions for a more accessible, sustainable higher education system that will better serve both students and employers. (https://www.christenseninstitute.org/higher-education/)

One of the most popular models of this type in the practice of higher education in the United States and Europe is the well-known development of American scientists H. Stacker and M. Horn from the Clayton Christensen Institute (USA), which shows different types of blended learning. (Staker H., 2013) This study emphasizes the mandatory use of the online environment. During traditional learning, every action of the student is controlled by the teacher, which leads to a lack of personal space, freedom. The online environment considers the possibility of freedom of expression, creativity, self-regulation. In this case, such freedom can exist only when the teacher does not control the actions of the student. Blended learning offers different learning models that the teacher chooses independently depending on the goals. It is important to understand that using a computer in the 
classroom does not always mean that blended learning is used. For example, if a teacher explains new material through a projector and students simply review it either on their devices or on the screen, then this is not an example of blended learning because students do not have the opportunity to do something with the material and choose their pace, time and place of its assimilation. There are many different models of blended learning with different efficiencies.

For example, the Clayton Christensen Institute identifies the following basic models: laboratory rotation, station rotation; flexible model and a la carte model.

The Online Learning Consortium (https://onlinelearningconsortium.org/) recently published an updated list of e-learning definitions. They list 7 types:

1. Classroom Course - Class activities are organized on scheduled classes.

2. Synchronous Distributed Course - Web technologies are used to expand classroom lectures and other activities for students on remote sites in real-time.

3. Web-Enhanced Course - The activities of the online course complement the lesson without reducing the number of required lessons

4. Blended (also called Hybrid) Classroom Course - online activities are combined with meetings in classrooms, replacing a significant percentage, but not all necessary training sessions.

5. Blended (also called Hybrid) Online Course - Most coursework is conducted online, but there is some necessary personal instruction, such as lectures, discussions, labs, or other personal learning activities.

6. Online Course - all course activities are carried out on the Internet; there are no necessary face-to-face classes during the course and there are no requirements for extracurricular activities.

7. Flexible Mode Course - offers several modes so that students can choose which one to use for educational purposes.

Blended learning models.

In total, there are more than 40 models of blended learning, we will focus on the most effective in our opinion. (https://www.christenseninstitute.org/blended-learning-definitions-and-models/)

1. Rotation model - students study according to a certain schedule or, at the discretion of the teacher, with different learning models, at least one of which is online learning. Other ways may include activities such as full group learning, group projects, one-on-one learning, and pencil and paper tasks. Students study mostly in the classroom (except for homework).

a. Station Rotation is one of the most efficient models. Students are divided into groups by type of activity and relevant goals: work with the teacher (feedback), online learning (development of skills of independent work) and project work (application of knowledge in solving practical problems, development of communication skills). Each group works in a separate part of the audience - the station and after completing the task change to visit each station. You can organize two or four stations (adding for example individual independent work). (John Watson, 2015)

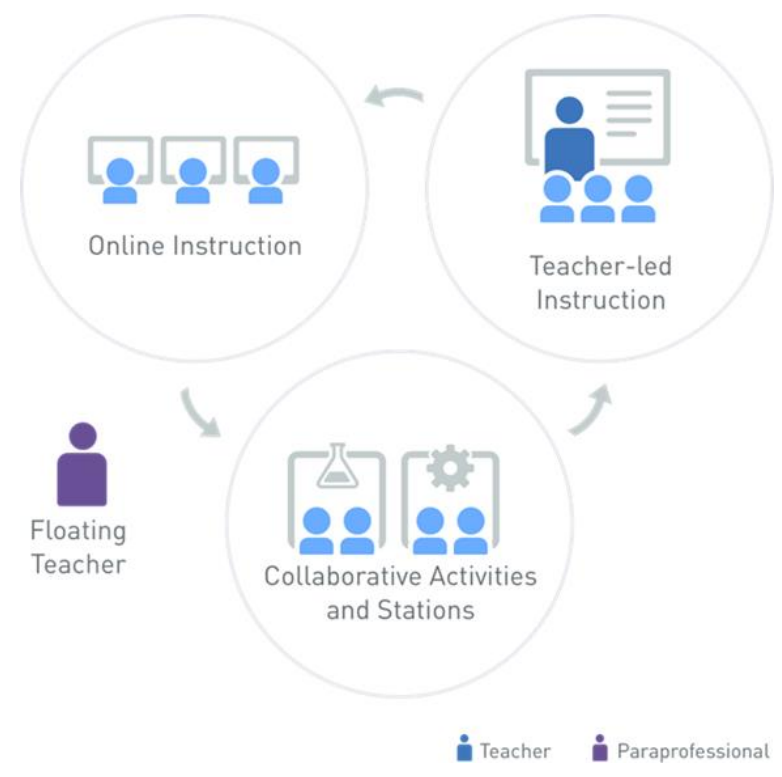


b. Lab Rotation is a course in which students move to a computer lab where they work individually online. Online you can process new material, consolidate what you have learned, train various skills and work on a personal project. An example of an online environment can be found at https://www.khanacademy.org /

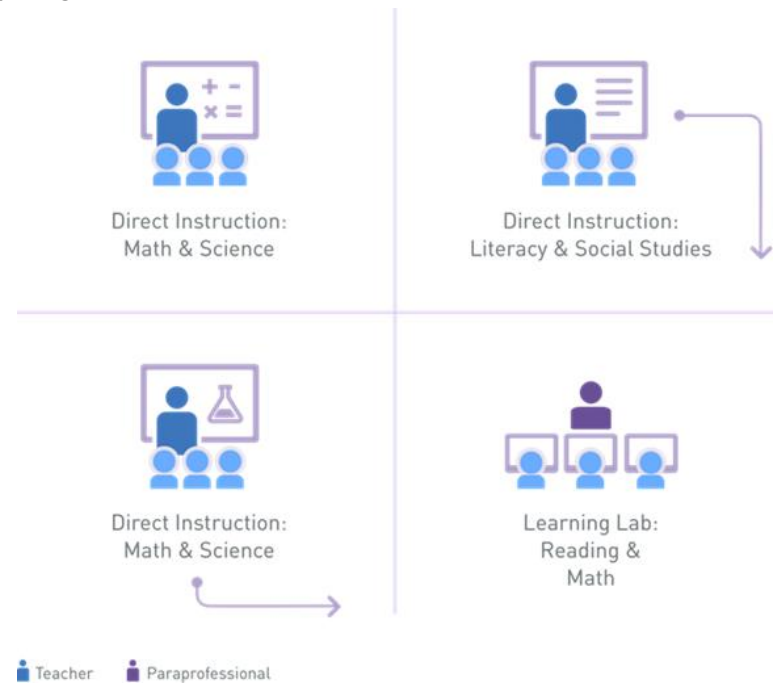

c. Flipped Classroom - the simplest model for implementation, in which students work at home in an online environment, where they get acquainted with the material in advance of the lesson, and then visit the university for a practical lesson with a teacher or project presentation.

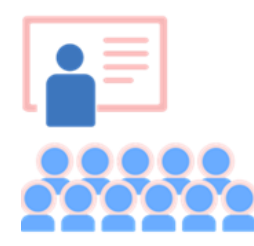

School: Practice and Projects

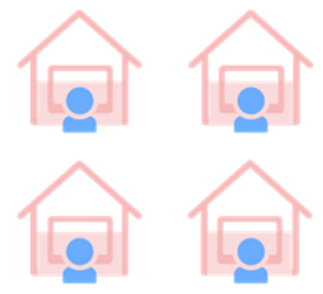

Home: Online Instruction and Content

d. Individual rotation - each student has an individual list of tasks or stations and does not have to visit all stations. The teacher sets an individual algorithm for students' schedules.

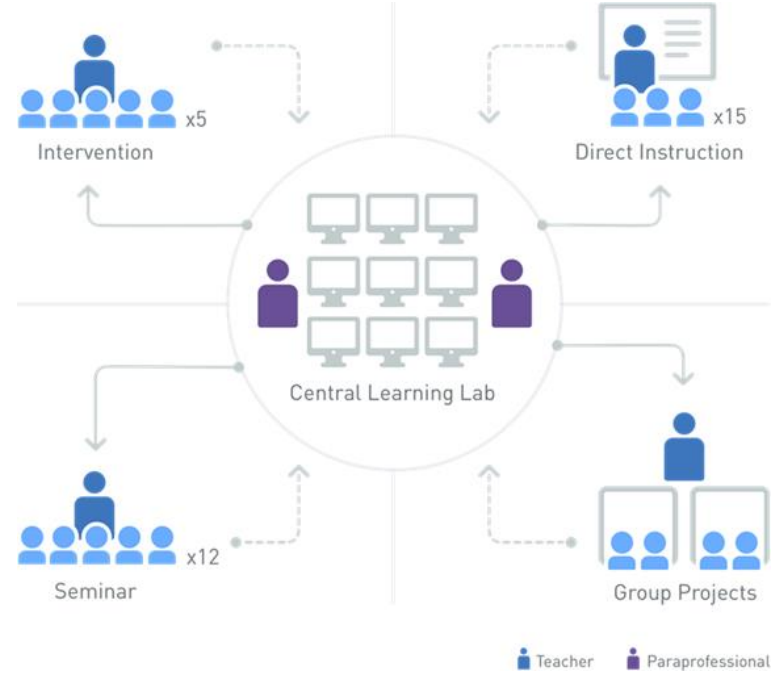


2. Flex model - online learning is the basis of student learning. Students are not limited by time, one or another type of educational activity, independently make a work schedule, choose a topic, pace. The teacher works with small groups or individually with students who need help. This model requires advanced self-organization skills. (Michael B. Horn)
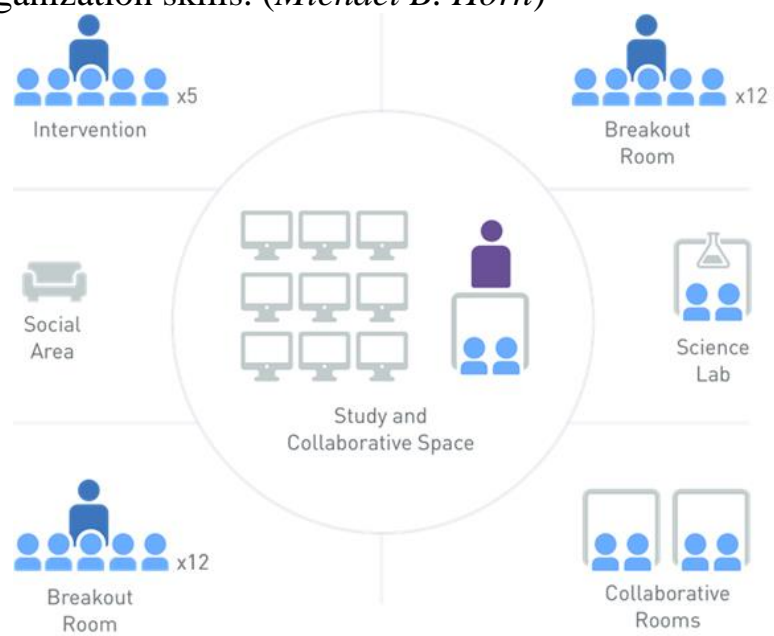

Study and

Collaborative Space

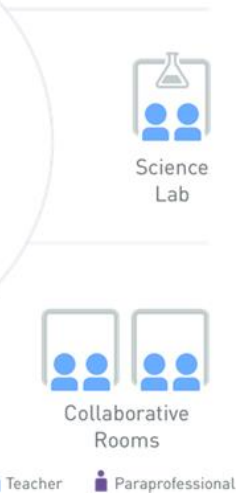

3. A La Carte model - A course that a student takes entirely online. The teacher in this model is an online teacher. Students can take the A La Carte course anywhere.
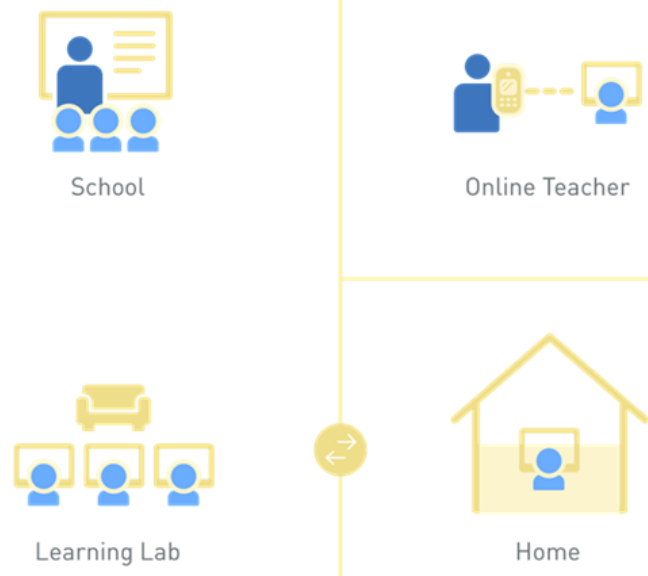

Online Teacher

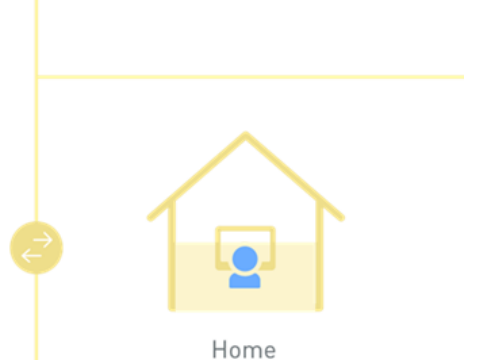

4. Enriched Virtual model - students need face-to-face training sessions with their teacher infrequently and then can take additional courses online. Online learning is the foundation of student learning when students are away. (Michael B. Horn, 2014)
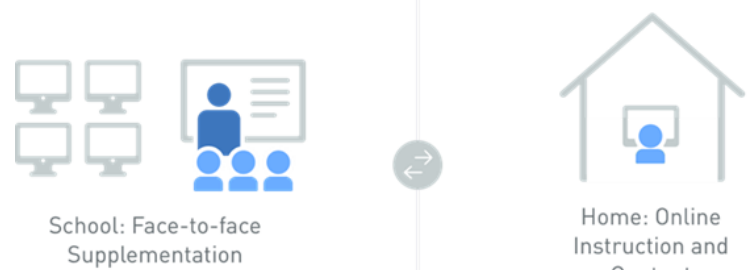

Home: Online Instruction and Content 


\section{Practical implementation. Experience of application in higher educational institutions.}

The concept of online education is relatively new, today, in our opinion, it best meets the challenges of modern society, improving the efficiency of students and allowing everyone to gain knowledge.

Blended Learning technology is widely used in universities around the world. United Kingdom: The Open University UK, Aston University, York University, Southern Cross University, James Cook University, Emas Business School, James Madison University, De Montfort University (https://www.distancelearningportal.com/articles/641/blended- learning-courses-combining-onlineand-on-campus-studies.html). USA: Arizona State University, Oregon State University, Georgia State's Webster, Columbia University, Falmouth University and others.

$\begin{array}{cccc}\text { For } & \text { example, } & \begin{array}{l}\text { Massachusetts_Institute_of_Technology } \\ \text { uses Thechnology Enhanced Active }\end{array} \text { Learning) project }\end{array}$ (https://scaleupserver.physics.ncsu.edu/wiki/pages/12m1C9c6/Massachusetts_Institute.ht_Technology). the full curriculum, including lectures with PowerPoint presentations, lecture notes, task sets, conceptual questions for use with personal interview tools, answers and visualizations (applets, movies, flash animations). They are available both on the iCampus project website and on the website.

Consider the specifics of the organization of work with one of the resources in the context of blended learning. We use the service "Google Class", which is a free online resource.

To prepare multi-person projects, students can use the online resource "Google Docs" to process documents, work with spreadsheets and create presentations online. The peculiarity of this service is that it allows you to work with documents simultaneously in a group with other users, work with Microsoft Office files and save the results in specified formats. The service ranks 6th in the list of "Top 200 Tools for Learning 2019" (https://www.toptools4learning.com/). All performance results are automatically saved on Google Drive. The convenience is that all Google services are linked by a single account, allowing users to communicate freely with other project participants in real-time. In our opinion, the service "Google Docs" allows you to competently organize the educational process and interaction. The teacher can comment, advise, make edits, leave comments on any part of the work online, which allows you to organize covert control of educational activities and track progress, thereby providing feedback to students through built-in chat. Additionally, Google provides the ability to create and attach to the document voice notes, videos.

Interesting is the opinion of Michael Horn https://michaelbhorn.com/, an expert on innovation, online learning, blended learning, competency-based learning and transforming the education system into a student-centred education, and Tech \& Learning Magazine https://www.techlearning .com / news / the-tech learning-10030-present named him one of the 100 most important people in creating and promoting the use of technology in education. In his report at the South Summit 2018, as part of the EnLighted educational conference, the scientist pointed out that "blended learning" is a natural approach due to the advantages of digital technology over analogue. He cites the example that in 2018, thirds of students in American universities attend online courses (at least one course is studied online). Among masters, $30 \%$ study online. 12 million school students take at least part of the program using blended teaching methods, i.e. about a quarter of all students in the United States. According to Michael Horn, the role of the teacher is also changing: "the task is not to retell the textbook but to instruct, motivate, help. No computer can do that, it takes a person." http://www.mbastrategy.ua/content/view/5150 (Michael B. Horn, 2014)

The Online Learning Consortium https://onlinelearningconsortium.org/ has identified hybrid (mixed) courses as integrating with online and traditional classes, face-to-face classes in a planned, defined manner. The flexibility of this model removes time and space constraints through online learning (which is especially true during a global pandemic), mixing with personal practice in the classroom. The blended model allows programs to better meet students' individual needs by providing more flexibility for a variety of schedules, using different learning styles and providing more preparation time.

Teachers can improve the quality of learning and interact more actively with students. (https://secure.onlinelearningconsortium.org/publications/survey/blended06)

It is worth noting the importance of research Pete Sharma (Pete Sharma) - teacher trainer, consultant and author of ELT. He works as a pre-session lecturer for EAP (English for Academic purposes) at Warwick University, UK, has worked for many years in the field of business English as a teacher-trainer and compiler of materials, regularly holds IATEFL conferences) and BESIG (Business English Special Interest Group). Pete Sharma has co-authored several books on technology Blended 
Learning (2007), 400 Ideas for Interactive Whiteboards (2011) in the Macmillan 'Books for Teachers' series, and How to Write for Digital Media (2014). (Barrett, B. and Sharma, P.) (https://oupeltglobalblog.com/2019/10/17/complete-guide-blended-learning/)

Advantages and disadvantages of using "blended learning".

Consider the main benefits of blended learning

$\checkmark$ Blended learning is important because it replaces traditional teaching methods that do not work for all students today, and now that we have access to modern technology and resources, we can tailor the learning experience to each student. Students can also learn through a variety of activities that relate to many different learning styles because blended learning models are better due to the growing role of information technology.

$\checkmark$ Blended learning also offers flexible time frames that can be personalized for each person, offering them the opportunity to learn at their own pace.

$\checkmark$ Blended learning methods are more learning-oriented. By posting teaching materials on the Internet, teachers allow their students to process lecture materials at their own pace.

$\checkmark$ Blended learning is more accessible and saves time. In other words, blended learning allows the student to access materials anywhere, anytime. The individual pace of learning reduces stress, promotes better assimilation of information.

$\checkmark$ Moreover, because the teacher provides most of the information online, it is possible to use the time in the audience in new and more diverse ways (more time for discussions, role-playing games, project presentations to develop communication skills).

$\checkmark$ In addition, in blended courses, students better develop their metacognitive skills in thinking about how they are learning and using additional online tools at their disposal to develop more personalized learning strategies.

$\checkmark$ Access to global resources and materials that meet the level of knowledge and interest of students provides the creation of individualized plans for meaningful professional development

$\checkmark$ E-learning allows you to organize more effective interaction between students and teachers through e-mail correspondence, platforms for discussion and chat.

$\checkmark$ Students have more tools to track their progress, assess what they may need more time for, and seek help from their peers or faculty, thus developing 21 st-century skills such as teamwork.

$\checkmark$ Finally, blended courses are also more accessible to students with special needs because they can use different types of study materials.

$\checkmark$ Extended time with students: the teacher has time for feedback with each student, who is not always enough during the lesson

$\checkmark$ Role differentiation is provided through improved access to learning materials. Blended learning can create opportunities to provide virtual instruction. Posting study materials online also allows students to use the materials to complement their learning experience.

There are some advantages of blended learning for students:

$\checkmark$ Motivation, increasing students' interest: when technologies are integrated into the educational process, students are more likely to be interested, focused on them and fascinated by the subject they are studying.

$\checkmark$ Focus of students on the subject being studied.

$\checkmark$ Blended learning ensures students' independence: the use of e-Learning materials increases the student's ability to set appropriate learning goals and take responsibility for their learning.

$\checkmark$ Development of real self-esteem: students become independent and responsible, tracking their achievements, which helps to develop the ability to find resources or receive the necessary help so that they can achieve their goals.

$\checkmark$ Instant assessment of work: the ability to quickly analyze, view and provide feedback on student work, allows the teacher to adapt his teaching methods and feedback for each student, increasing the efficiency of time.

$\checkmark$ Allows students to study at their own pace. Thanks to the flexibility of blended learning and the ability to access Internet resources, it allows students to learn at their own pace, ie the teacher can help speed up the learning process or provide the necessary better resources.

$\checkmark$ Prepares students for the future: Blended learning offers many skills in the real world that directly translate into life skills (self-organization, self-education, decision making, research skills, etc.). 
Despite the obvious advantages, blended learning has several disadvantages.

- The main problem of blended learning today is access to the World Wide Web.

- Blended learning is the latest technology, so to master it you need to teach teachers, first and then students. This may take some time and effort.

- Teachers and students need to quickly master online learning tools, work in groups and participate in discussions. Students may need additional support in the early stages.

Conclusions. The integration of innovative technologies into the educational process allows to improve the level of teaching, involve students in cooperation, the development of students' skills of the XXI century.

Blended learning is more important today than ever, no matter what the industry, from schools to corporations, in all walks of life, especially during the pandemic.

All students, regardless of age, study differently, teaching methods must take this into account, teachers must develop curricula to cover the visual, auditory and kinetic types of student perception. Thus, the prospect of blended learning technology lies in its flexibility and integrativeness concerning the various components of the educational process. Difficulties in selecting teaching aids from the vast number of resources and services that exist in the Web space can be avoided by creating and disseminating the latest teaching methods and technologies, guidelines and algorithms for their use that meet the challenges of society.

In our opinion, the introduction of Blended Learning in the educational process gives IT students the opportunity to find the necessary material online, perform test tasks, testing their knowledge, master professionally oriented skills, work with additional resources, use video and audio recordings, which will lead to the highest quality mastery of the material, thus improving and optimizing the educational process.

At the same time, we must not forget about the responsibility of teachers in the use of innovative learning technologies. When planning a blended learning course, the teacher needs to realistically assess their readiness to teach the subject at a high level to ensure that the main goal of effective learning is achieved.

We agree with the opinion of reputable scholars around the world that today "blended learning" is an almost universal way of education, which combines traditional and e-learning technologies and meets the individual needs of students.

\section{REFERENCES}

1. Adams Becker S., Cummins M., Davis A., Freeman A., Hall Giesinger C., Anantha-narayanan V. NMC Horizon Report. Higher Education Edition. Austin, Texas: The New Media Consortium, 2017. Retrieved from http://cdn.nmc.org/media/2017-nmc-horizon-report-he-EN.pdf

2. Banados E. A blended-learning pedagogical model for teaching and learning EFL successfully through an online interactive multimedia environment // CALICO Journal. 2006. № 23 (3). P. 533-550.

3. Barrett, B. and Sharma, P. (2007) Blended Learning: using technology in and beyond the language classroom. Oxford: Macmillan.

4. Bax, S., 2003. CALL - past, present and future. System 31 (1), 13-28.

5. Bonk C. J. \& Graham C. R. Handbook of blended learning: Global Perspectives, local designs. - San Francisco, CA: Pfeiffer Publishing, 2006.

6. Bonk C. J., Graham C. R. The Handbook of blended learning: Global perspectives, local designs. San Francisco, CA: Pfeifer; 2006.

7. Caudwell, R. (2018) Listening - beware the smiling-class imperative In Modern English Teacher Volume 28 Issue 1.

8. Dudeney G., Hockly N. How to... Teach English with Technology. - Harlow: Pearson Education Limited, 2007. Stracke E. A road to understanding: A qualitative study into why learners drop out of a blended language learning (BLL) environment // ReCALL. 2010. № 19 (1). P. 57-78. 10.5.

9. Elke Stracke (2009) Spotlight on Blended Language Learning: A frontier beyond learner autonomy and computer assisted language learning. Retrieved from https://pdfs.semanticscholar.org/bdde/ad64d27aaae2819f6ec6c6fff40516837980.

10. Fandei V.A. Teaching through Technologies: Communicative and Information Competences / V.A. Fandei // Global Partners in Education Journal. - 2011. - Vol. 1, No. 1. - P. 8.

11. Friesen N. Defining Blended Learning. Retrieved from http://learningspaces.org/papers/Defining_Blended_ Learning_NF.pdf 
12. Garrison D. R., Vaughan N. D. Blended learning in higher education: Framework, principles, and guidelines. San Francisco, CA: Jossey-Bass, 2008. DOI: 10.1002/9781118269558. Publisher: John Wiley \& Sons.

13. Garrison, R., \& Kanuka, H. (2004). Blended learning: Uncovering its transformative potential in higher education. Internet and Higher Education, 7(2), 95-104. Cooperative Learning in the Classroom by David W. Johnson, Roger T. Johnson, Edythe J. Holubec 110 pages. Publisher: Association for Supervision and Curriculum (November 1, 1994).

14. Graham C. R. Blended learning systems: Definition, current trends, and futu-re directions // Bonk C. J., Graham C. R. The handbook of blended learning: Global perspectives, local designs. San Francisco, CA: Pfeiffer Publishing, 2006. P. 3-21.

15. Gruba, P. and Hinkelman, D. (2012) Blended Learning Technologies in Second Language Classrooms Palgrave Macmillan 2012: Basingstoke.

16. Hockly, N. (2016) Focus on Learning Technologies Oxford: OUP.

17. Project EDUCAUSE. 2018 Key Issues in Teaching and Learning. Retrieved from https://www.educause.edu/eli/initiatives/key-issues-in-teaching-and-learning; https://www.educause.edu/eli/initiatives/key-issues-in-teaching-and-learning-2018

18. John Watson. Blended Learning: The Evolution of Online and Face-to-Face Education from 2008-2015.

19. Kerr, P. (2014) Adaptive Learning. Retrieved from http://the-round.com/wpcontent/uploads/downloads/2014/07/A-Short-Guide-to-Adaptive-Learning-in-English-Language-Teaching2.pdf

20. McCarthy, M. (2016) Ed the Cambridge Guide to Blended Learning for Language Teaching Cambridge: Cambridge University Press

21. Means B., Toyama, Y., Murphy, R., Bakia, M. and Jones, K. (2010) Evaluation of Evidence-Based Practices in Online Learning: A Meta-Analysis and Review of Online Learning Studies U.S. Department of Education. Retrieved from https://www2.ed.gov/rschstat/eval/tech/evidence-based-practices/finalreport.pdf

22. Michael B. Horn and Heather Staker, Blended: Using Disruptive Innovation to Improve Schools (San Francisco: Jossey-Bass, 2014).

23. Michael B. Horn, Heather Staker, Clayton M. Christensen. Blended: Using Disruptive Innovations to Improve Schools.

24. Procter C. T. Blended Learning in Practice // Education in a Changing Environment Conference Proceedings. 2003. Retrieved from https://www.rese-archgate.net/publication/277177316

25. Sharma, P (2010) Key concepts in ELT: Blended learning ELT Journal Vol 64 (4) Oxford: Oxford Academic. Retrieved from https://academic.oup.com/eltj/article/64/4/456/390082

26. Sharma, P. and Barrett, B. (2018). Best Practices for Blended Learning Hove: Pavilion Publishing and Media Ltd.

27. Sharma, P. and Westbrook, K. (2016) Online and blended language learning in The Routledge Handbook of Language Teaching and Technology Eds Fiona Farr and Liam Murray Abingdon: Routledge

28. Staker H., Horn M. B. Classifying K-12 Blended Learning. Retrieved from http://www.christenseninstitute.org/wp-content/uploads/2013/04/Clas-sifying-K-12-blended-learning.pdf

29. Staker H., Horn M. B. Classifying K-12 Blended Learning. Retrieved from http://www.christenseninstitute.org/wp-content/uploads/2013/04/Clas-sifying-K-12-blended-learning.pdf

30. Tanu R. Kellnerova. How to teach mixed-ability classes // Insight Intermediate How to ... guides. Oxford: Oxford University Press, 2014. C.23-29.

31. Tim Bowen. Classroom management: teaching mixed-ability classes. Retrieved from http://www.onestopenglish.com/methodology/methodology/classroommanagement/classroommanagementteaching-mixed-ability-classes/146453.article

32. Wang Y., Han X., Yang J. Revisiting the Blended Learning Literature: Using a Complex Adaptive Systems Framework // Educational Technology \& So-ciety. 2015. № 18 (2). P. 380-393.

33. Whittaker, C. and Tomlinson, B. (2013) [Eds] Blended Learning in English Language Teaching: Course Design and Implementation London: British Council Retrieved from https://www.teachingenglish.org.uk/sites/teacheng/files/pub_D057_Blended\%20learning_FINAL_WEB\%2 0ONLY_v2.pdf

34. Retrieved from www.etprofessional.com/best-practices-for-blended-learning

35. Retrieved from https://peacheypublications.com/10-free-tools-for-building-blended-online-learning

36. Retrieved from https://www.christenseninstitute.org/

37. Retrieved from https://www.teachthought.com/learning/12-types-of-blended-learning/

38. Retrieved from http://www.blendedlearning.org/models/ 